\title{
TATALAKSANA RECURRENT INTRA ORAL HERPES DISERTAI CANDIDIASIS YANG DIRUJUK OLEH DERMATOLOGIST
}

\author{
Raziv Ganesha ${ }^{1}$, Dwi Setyaningtyas ${ }^{2}$, Diah Savitri E ${ }^{3}$, Priyo Hadi ${ }^{3}$, Israyani ${ }^{4}$. \\ ${ }^{1}$ Bagian Penyakit Mulut, Fakultas Kedokteran Gigi Universitas Mahasaraswati Denpasar \\ ${ }^{2}$ Spesialis Penyakit Mulut, Departemen Gigi \& Mulut, Rumah Sakit Angkatan Laut (RSAL) Dr Ramelan, Surabaya \\ ${ }^{3}$ Departemen Penyakit Mulut Fakultas Kedokteran Gigi Universitas Airlangga Surabaya \\ ${ }^{4}$ Departemen Penyakit Mulut Fakultas Kedokteran Gigi Universitas Hasanuddin Makassar \\ E-mail: raziv.ganesha@unmas.ac.id
}

\begin{abstract}
Introduction : Herpes simplex virus (HSV) is one variant of the herpes virus that infects humans, has two main types of HSV-1 that manifests more found in the mucosa of the mouth, pharynx, and skin (upper waist), and the type HSV-2 manifests in the genital area (lower waist). Case: 16-year-old female patient were referred from dermatologis RSAL Dr Ramelan Surabaya with complaints of many ulcers, whitish area of the tongue, palatum, vestibulum and genitals. Case Treatment: patients treated with systemic drugs of acyclovir, fluconazole, folic acid, vitamin B, vitamin C, methyl prednisolone, aloe vera extract topical. Patients were tested for blood, HSV-1 \& HSV-2 (+), HIV (-), ANA (). Discussion: Herpes simplex infection is a disease caused by the herpes simplex virus (HSV) which is a DNA virus (Deoxyribonucleic acid). In humans, the herpes virus can be latent and reactivate Reactivation can occur because of a trigger in the form of decreased immunity due to weather changes, fever, sun exposure, emotional stress, trauma, pregnancy, hormonal, systemic diseases, allergies, and immunosuppression. In this case the cause is thought to be due to hormonal. The diagnosis of primary HSV infection and recurrent infection is usually obtained from clinical features and laboratory tests are used establish the diagnosis. Conclucion: Recurrence of HSV infection can be reduced if avoid trigger factors. HSV infection management aimed at the control of pain, supportive treatment and definitive treatment. In this case, multidisciplinary collaboration is required in the treatment because it involves two sites, oral and genital.
\end{abstract}

Keywords : HSV, Recurrent Herpes Oral, Oral Candidiasis

\section{PENDAHULUAN}

Sejak beberapa tahun lalu, telah banyak penelitian membuktikan bahwa infeksi disebabkan oleh berbagai macam mikroorganisme. Mikroorganisme dapat melakukan transmisi dan paling sering melalui perlekatan pada permukaan kulit, saluran pernafasan, saluran pencernaan bahkan melalui transmisi seksual. Virus merupakan mikroorganisme yang bersifat patogen dan penyebab dari infeksi klinis baik akut maupun kronis, dan dapat menyerang sejumlah organ tubuh. ${ }^{1}$

Virus herpes simpleks (HSV) adalah virus DNA, yang merupakan salah satu varian virus herpes yang menginfeksi manusia memiliki dua tipe utama yaitu HSV-1 yang bermanifestasi lebih banyak ditemukan pada mukosa mulut, faring, serta kulit (pinggang ke atas), dan tipe HSV-2 yang bermanifestasi pada daerah genital (pinggang ke bawah), akan tetapi pada masa sekarang dengan adanya perubahan perilaku seksual maka tidak jarang pula dapat ditemukan kondisi sebaliknya.

Penyakit yang disebabkan oleh infeksi virus HSV dapat berupa infeksi primer akibat kontak pertama dengan virus atau infeksi sebagai bentuk reaktivasi atau rekurensi akibat aktivasi virus yang laten atau dormant. ${ }^{2,3,4}$ Infeksi HSV-1 dan HSV-2 dapat terjadi di seluruh belahan dunia tanpa mengenal musim. Semua orang dapat terinfeksi virus ini dan semua virus yang telah mengalami masa laten dapat teraktivasi kembali. ${ }^{5}$

Pada beberapa negara berkembang, insiden terjadinya infeksi HSV melalui serokonversi yaitu sekitar $20 \%$ pada usia atau kurang dari 5 tahun dan sekitar $70-80 \%$ pada usia remaja dan dapat meningkat sekitar $40-60 \%$ pada usia 20-40 tahun. Rekurensi antara pria dan wanita memiliki perbandingan 2.7:1.9 kali per 100 hari. Pada wanita dengan herpes genital stadium awal dapat menunjukkan infeksi yang asimptomatik dengan angka kejadian 12\% untuk HSV-1 Primer, 18\% untuk HSV-2, dan 23\% untuk infeksi non-primaryHSV-2. ${ }^{5}$ Tujuan pada laporan kasus ini akan dibahas mengenai tatalaksana recurrent intra oral herpes disertai pada pasien rawat inap yang dirujuk dokter spesialis kulit dan kelamin.

\section{KASUS}

Pasien wanita usia 16 tahun dikonsulkan dari ruang rawat inap kulit dan kelamin dengan keluhan terdapat banyak sariawan di dalam mulut, disertai area keputihan pada lidah dan luka pada kemaluan. Pasien mulai masuk rumah sakit sejak 3 hari lalu. Pasien didiagnosis infeksi HSV 1 dan 2. Pasien mengatakan keluhan pasien dirasakan sejak 1 bulan yang lalu. Keluhan seperti ini sudah dirasakan pasien secara berulang sejak \pm 3 tahun yang lalu dan sudah menjalani pemeriksaan dimana-mana. Kondisi saat ini paling parah sehingga harus dirawat inap di rumah sakit.

Pasien mengatakan karena banyak sariawan pasien menjadi susah makan dan berbicara, selain itu juga mengalami kesulitan saat buang air kecil. Kondisi ini sering terjadi menjelang menstruasi. Kondisi seperti ini bila muncul biasanya diawali dengan demam namun kadang demam muncul setelah sariawan atau luka dikemaluan muncul. Kondisi saat ini pasien sedang demam. Pasien mengatakan sariawan pada mulut dan luka pada kemaluan sering muncul bersamaan. Pada 
anamnesis dikatakan saat ini pasien sedang tinggal di asrama putri dan mengaku kebersihan diri kurang dijaga ditambah dengan kegiatan asrama menguras tenaga karena padat dan waktu istirahat yang kurang. Selama dirawat inap pasien susah makan sehingga tubuh sangat lemah.

Perawatan yang sudah diberikan dokter spesialis kulit kelamin adalah infus RL (Ringer Laktat), acyclovir $5 \times 800 \mathrm{mg}$, vitaneuron $1 \times 1$, fluconazole $2 \times 1$, asam folat $1 \times 1$, ranitidine $2 \times 1$. Pada pasien telah membawa hasil pemeriksaan tes HSV-1 dan HSV-2 dengan hasil reaktif, dokter spesialis kulit dan kelamin juga telah merujuk ke patologi klinik untuk dilakukan tes rapid HIV dengan hasil dinyatakan negatif.

Pada pemeriksaan klinis ekstra oral terdapat deskuamasi pada bibir hingga sudut mulut, multiple, mudah berdarah dan sakit. Pada pemeriksaan intra oral pada palatal, dorsal, ventral dan lateral lidah terdapat ulcer, multiple, bentuk oval, ukuran bervariasi, warna putih dengan tepi kemerahan, batas jelas, sakit. Pada dorsal lidah terdapat pseudomembran warna putih, multiple, dapat dikerok, mudah berdarah dan sakit.(gambar.1)
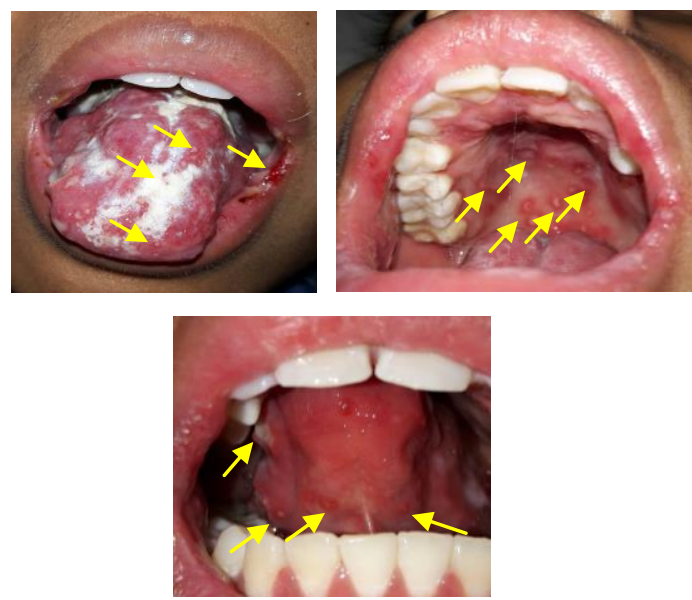

Gambar. 1 foto kunjungan pertama : terdapat ulcer multiple, bentuk bulat, ukuran bervariasi, warna keputihan tepi kemerahan, pada palatum, dorsal lidah, ventral lidah dan labial. Terdapat pseudomembran, warna keputihan, bentuk tidak beraturan, ukuran bervariasi pada dorsal lidah.

\section{TATALAKSANA KASUS}

Dari hasil pemeriksaan klinis dan anamnesis pasien didiagnosis recurrent intra oral herpes disertai acute pseudomembranous candidiasis, dengan diagnosis banding Syndrome Bechet. Pasien kemudian diresepkan aloe vera extract oral rinse $60 \mathrm{fl}$ no I yang dipakai $3 \mathrm{kali}$ sehari, aloe vera ectract gel $8 \mathrm{ml}$ tube no 1 yang dipakai 4 kali sehari dan susu entrasol 2 kali sehari. Pasien dikonsulkan untuk dilakukan pemeriksaan ANA Tes. Pasien diinstruksikan untuk diet lunak dan minum air putih yang banyak. Pasien diinstruksikan untuk menjaga kebersihan rongga mulut dan genital.

Pada pemeriksaan ANA Test didapat hasil negative. Pasien dilakukan oral health care setiap hari selama 8 hari kemudian diizinkan pulang dari rawat inap dan diinstruksikan untuk kontrol rawat jalan 5 hari setelah pulang.

Pada kontrol di poliklinik gigi dan mulut pasien mengatakan muncul sariawan baru pada lidah, sariawan di langit-langit sudah membaik, sedangkan luka pada genital masih ada tapi nyeri sudah berkurang. Pasien mengatakan sudah bisa makan dan istirahat yang baik.

Pasien kemudian diberikan resep methylprednisolone 3x sehari, vitamin B \& C 1x sehari dan diinstruksikan untuk kontrol 1 minggu kemudian. Pada kontrol 1 minggu kemudian pasien mengatakan luka pada rongga mulut dan genital sudah sembuh. Dari pemeriksaan objektif tidak terdapat kelainan.(Gambar 2)

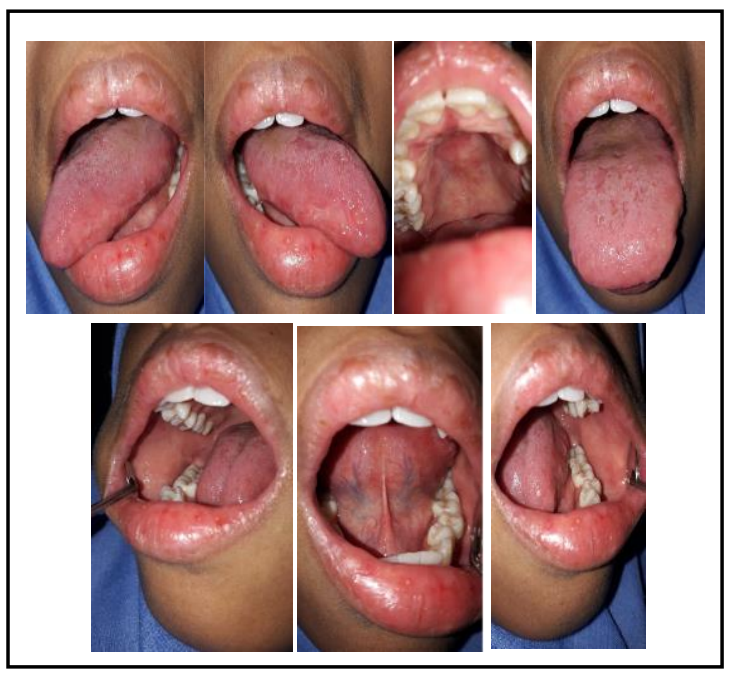

Gambar 2. Foto kontrol sudah tidak terdapat lesi pada daerah dorsal lidah, ventral lidah dan palatal

Pasien diinstruksikan untuk selalu menjaga kebersihan rongga mulut dan genital, mencegah transmisi dengan cara tidak memakai alat-alat makan, perlengkapan mandi secara bergantian, dan menjaga asupan nutrisi serta kontrol kembali jika mengalami kekambuhan.

\section{PEMBAHASAN}

Infeksi herpes simpleks adalah penyakit yang disebabkan oleh virus herpes simpleks (HSV) yang merupakan virus DNA (Deoxyribonucleic acid). Pada manusia, virus herpes bisa bersifat laten dan dapat mengalami reaktivasi. Kemungkinan terjadi rekurensi lesi sebesar $40 \%$. Lesi infeksi rekuren bermanifestasi dalam dua bentuk, yaitu lesi yang sering terjadi pada daerah di perioral yang dikenal dengan nama herpes labialis, dan lesi pada rongga mulut yang disebut recurrent intra oral herpes (RIOH). ${ }^{4}$ Penularan virus HSV-1 terutama dengan kontak mulut dengan mulut, kontak dengan luka, saliva dengan penderita HSV-1, sedangkan penularan virus HSV-2 terutama pada kontak seksual, kontak kulit, kontak dengan luka atau cairan dengan penderita HSV-2, selain itu penularan HSV-2 juga bisa ditularkan dari ibu yang terinfeksi HSV-2 kepada bayinya. ${ }^{6}$ Reaktivasi dapat terjadi karena adanya pemicu berupa penurunan kondisi imunitas karena perubahan cuaca, demam, paparan sinar matahari, stress emosional, trauma, menstruasi, penyakit sistemik, alergi, dan imunosupresi. ${ }^{2,7}$ 
Pada kasus ini dugaan yang memicu kekambuhan adalah terkait hormonal, dimana dalam pernyataan pasien sering mengalami kondisi ini saat menjelang menstruasi. Pada masa siklus menstruasi akan terjadi perubahan hormon yang mengakibatkan perubahan pada system imun sehingga memicu reaktivasi dari virus HSV. Perubahan hormon ini adalah terjadi peningkatan hormon estrogen, peningkatan hormon estrogen ini akan mengurangi sel T CD4 dan sel $\mathrm{T}$ CD8 yang memiliki peranan penting dalam mengendalikan reaktifasi virus HSV. Sehingga saat terjadi penurunan sel T CD4 dan sel T CD8 maka tidak dapat melindungi virus HSV tetap laten dan menjadi reaktifasi. $^{8}$

Kondisi lain yang memicu kekambuhan pada kasus ini adalah kondisi kelelahan dan stres yang dialami pasien saat di asrama. Stres fisik dan mental dapat menyebabkan peningkatan sekresi ACTH yang mengakibatkan kenaikan level kortisol melalui meningkatnya aktivitas Hipothalamus -Pituitari Axis. ${ }^{9}$ Reaktivasi dari fase laten HSV-1 pada pasien ini disebabkan karena meningkatnya level kortikosteroid endogen yang dihasilkan cortex adrenal pada saat stres. Pada keadaan stres baik fisik maupun psikis menyebabkan berkuranganya sirkulasi populasi sel-sel imun seperti sitokin (IL-6, TNF $\alpha$ ) sel B limfosit, NK cell, dan monosit yang mendorong reaktivasi HSV $-1 .^{10}$

Pada kasus ini terjadi infeksi jamur. Terdapat beberapa komplikasi pada pasien dengan infeksi HSV salah satunya adalah infeksi jamur dimana saat terjadi infeksi HSV akan terjadi penurunan system imun yang membuat jamur yang merupakan flora normal pada rongga mulut menjadi pathogen. ${ }^{11}$ Pada kasus ini pasien diberikan Fluconazole untuk mengatasi infeksi jamur. Mekanisme kerja dari fluconazole adalah dengan menghambat enzim lanosterol 14a-demethylase, enzyme microsomal, yang dihasilkan sitokrom P450 pada membrane sel jamur. penghambatan enzym

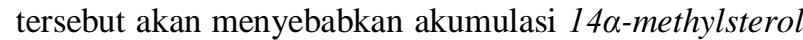
sehingga mengganggu permeabilitas membran, menurunkan aktifitas enzym, baik yang membentuk membran sel maupun yang menghidrolisis protein membran sel host. Akibatnya sel jamur nekrosis dan mati. Kelebihan Fluconazole dibandingkan obat anti jamur lainnya yaitu absorpsinya tidak terganggu oleh metabolisme makanan dan keasaman lambung, memiliki waktu paruh yang lama (25-30 jam), tidak terganggu oleh metabolism hati, terbukti secara in vivo tidak hepatoksik, terdifusi dengan baik ke cairan cerebrospinal, saliva, jaringan vagina, sputum, kulit dan cairan pada lesi. ${ }^{12}$

Diagnosis infeksi HSV primer dan infeksi rekuren biasanya diperoleh dari gambaran klinis dan pemeriksaan laboratorium digunakan untuk menegakkan diagnosis. Isolat HSV dari kultur sel merupakan gold standard untuk diagnosis karena virus langsung tumbuh pada kultur jaringan. Polymerase chain reaction (PCR) dari hasil apusan merupakan metode terbaru yang terbukti dapat mendeteksi antigen HSV tiga sampai empat kali lebih baik dibanding kultur, PCR yang dilakukan tepat waktu juga terbukti sangat sensitif dan spesifik. HSV dapat diidentifikasi melalui scraping pada dasar lesi (vesikula) yang kemudian diapus pada glass slide. Apusan kemudian dapat diwarnai dengan pewarnaan Wright, Giemsa (preparat Tzanck), atau Papanicolaou. Preparat apusan yang sama juga dapat digunakan untuk uji deteksi antigen fluorosensi langsung menggunakan antibodi monoklonal terhadap HSV. Selain itu Infeksi HSV primer berkaitan dengan peningkatan titer immunoglobulin- $M$ (IgM) yang timbul dalam beberapa hari, diikuti oleh peningkatan titer $\operatorname{IgG}$ permanen beberapa minggu kemudian (serokonversi) yang mengindikasikan adanya infeksi sebelumnya, tetapi tidak memberikan perlindungan atau tidak dapat mencegah kemungkinan terjadinya reaktivasi. Infeksi recurrent herpes simplex dihubungkan dengan peningkatan titer antibodi IgG pada kondisi akut dan proses penyembuhan. ${ }^{3,4}$ Pada pasien ini hasil dari tes IgG HSV menunjukkan hasil reaktif.

Pada kasus ini diagnosis banding adalah Syndrome Bechet's, merupakan penyakit kronis, relaps, vaskulitis sistemik yang tidak diketahui etiologinya. ${ }^{13}$ Mekanisme imun (autoimun) dan faktor genetik (HLAB5 dan HLA-DR5 Alloantigen) dianggap memiliki peran. Beberapa studi menerangkan agen infeksius seperti HSV-1 dan Streptococcus sanguis sebagai faktor pencetus. $^{14,15,16,17}$ Penegakan diagnosis pada Syndrome Bechet's mengacu pada International Classification Criteria of Behcet's Disease tahun 1990, yaitu kriteria mayor berupa ulcer oral rekuren dengan 2 kriteria minor, antara lain ulcer genital rekuren, lesi pada mata, lesi kulit atau hasil tes patergi (uji hiperaktivitas kulit) positif. ${ }^{18,19,20}$ Pada pasien ini memenuhi kriteria mayor yaitu ulcer oral rekuren dan hanya 1 kriteria minor yaitu ulcer genital rekuren, sedangkan tes patergi belum bisa dilakukan karena keterbatasan peralatan.

Penatalaksanaan infeksi HSV ditujukan pada kontrol rasa sakit, perawatan suportif dan perawatan definitif. ${ }^{4}$ Pada kasus ini untuk kontrol rasa sakit diberikan terapi dengan aloe vera extract topikal berfungsi membentuk lapisan tipis dan bertindak sebagai barrier untuk melindungi ujung saraf dari lesi sehingga terhindar dari iritasi dan juga mengurangi rasa sakit selain itu kandungan aloe vera dan asam hyaluronat yang berformulasi dapat mendukung penyembuhan dari kerusakan jaringan.

Banyak obat-obatan antivirus yang digunakan untuk mengatasi dan menghambat sintesis DNA virus. Cara kerja obat antivirus tersebut dengan menghambat langsung polymerase DNA virus dengan cara bersaing dengan nukleosida trifosfat (acyclovir, gansiclovir, dan penciclovir), merusak rantai DNA yang sedang fase replikasi (acyclovir), atau merusak rantai DNA setelah penggabungan nukleotida buatan dalam DNA virus. ${ }^{21}$

Acyclovir merupakan analog nukleosida guanosine dan melalui fosforilase mengubah keadaan aktifnya oleh timidin kinase virus. Afinitas acyclovir untuk herpes virus yang dikodekan timidin kinase 200 kali lebih besar daripada timidin kinase manusia sehingga fosforilasi acyclovir oleh enzim manusia menjadi tidak berarti. Afinitas selektif ini menghasilkan aktivasi dan konsentrasi acyclovir pada sel yang yang terinfeksi virus. Setelah fosforilasi menjadi acyclovir monofosfat (aciclo-GMP) dan acyclovir trifosfat (aciclo-GTP). Nukleosida trifosfat adalah penghambat 
potensial sintesis DNA virus yang bersaing dengan nukleotida virus untuk dimasukkan ke dalam DNA virus sehingga menghasilkan DNA virus nonfungsional yang akhirnya menghambat replikasi virus. ${ }^{21,22}$

Pemberian Methylprednisolone berfungsi sebagai antiinflamasi untuk meredakan ulcer yang luas, eritema dan nyeri. Methylprednisolone termasuk kortikosteroid yang bersifat intermediate acting, mempunyai half-life 12-36 jam dan retensi natrium rendah sehingga dapat menurunkan kemungkinan timbulnya efek samping. Dosis yang diberikan dapat rendah atau tinggi sesuai tingkat keparahan penyakit untuk pengendalian penyakit. Mekanisme antiinflamasi yaitu adanya pelepasan lipokortin yang memiliki aksi inhibisi langsung terhadap fosfolipase A2 dalam sel dengan cara menginduksi proses fosforilasi enzim, menghambat pembentukan prostaglandin, leukotrin dan derivat jalur asam arakidonat. Kortikosteroid juga menghambat produksi dan pelepasan sitokin, termasuk interleukin (IL-1), IL-6 dan tumor nekrosis factor (TNFa) makrofag, sel langerhans, monosit. Sitokin-sitokin ini terlibat dalam aktivasi sel $\mathrm{T}$ dan mencetuskan kaskade imunoreaktif. Pemberian kortikosteroid sistemik secara tapering-off untuk mencegah terjadinya efek withdrawal karena terdepresinya poros Hipotalamus-PituitaryAdrenal yang bisa timbul apabila dilakukan penghentian secara tiba-tiba. ${ }^{23,24,25}$ Pada kasus ini diberikan methylprednisolone berfungsi untuk mempercepat proses penyembuhan.

Pada perawatan suportif untuk pasien ini diberikan susu entrasol untuk meningkatkan nutrisi sehingga mampu meningkatkan system imun yang kemudian akan mempercepat penyembuhan, Vitamin B kompleks dalam bentuk koenzim berperan sebagai katalis dan regulator pada reaksi biokimia dalam tubuh sehingga dapat meningkatkan daya tahan tubuh penderita melalui kecukupan asupan vitamin yang dibutuhkan dan mencegah terjadinya gangguan metabolik fungsional yang menyebabkan berkurangnya asupan vitamin. Vitamin $\mathrm{C}$ berperan sebagai koenzim dan antioksidan. Vitamin $\mathrm{C}$ dapat mempercepat perubahan residu prolin dan lisin pada prokolagen menjadi hidroksiprolin dan hidroksilisin pada sintesis kolagen. Sehingga dapat mempercepat proses kesembuhan. $^{24}$ Asam folat diperlukan untuk sintesis asam nukleat (termasuk DNA) dan asam amino, sehingga vital untuk pembentukan jaringan baru. ${ }^{26}$

Pada kasus ini pasien diberikan edukasi dan instruksi untuk pencegahan transmisi dengan cara tidak bergantian dalam pemakaian alat makan dan selalu menjaga kebersihan rongga mulut serta menjaga kebersihan genital. Pasien juga diinstruksikan untuk beristirahat yang cukup serta menjaga asupan nutrisi dengan makan makanan tinggi kalori dan tinggi protein karena kalori diperlukan untuk mempertahankan jaringan tubuh serta mempertahankan suhu tubuh. Sedangkan pemberian protein yang adekuat penting dalam proses penyembuhan luka serta kekebalan tubuh. $^{27}$

\section{SIMPULAN}

Rekurensi dari infeksi HSV dapat ditekan jika menghindari faktor pencetus seperti stress,
Penatalaksanaan infeksi HSV ditujukan pada kontrol rasa sakit, perawatan suportif dan perawatan definitif. Pada kasus ini diperlukan kerja sama multidisiplin ilmu dalam penanganannya karena melibatkan dua lokasi yaitu oral dan genital.

\section{UCAPAN TERIMA KASIH}

Penulis mengucapkan terimakasih kepada Rumah Sakit Angkatan Laut Dr. Ramelan dan Program Pendidikan Dokter Gigi Spesialis (PPDGS) Ilmu Penyakit Mulut (IPM) FKG Universitas Airlangga Surabaya sebagai sarana sebagai klinisi untuk meningkatkan pengetahuan. Laporan kasus ini tidak mendapat dana hibah dari perorangan atau institusi manapun dalam proses pembuatannya.

\section{DAFTAR PUSTAKA}

1. Kumar,V., Abbas, A. \& Aster,J.C., 2015. Robbins and Cotran: Pathologic Basis of Disease 9th Ed. william schmitt, ed., Philadelphia: Elseiver Ltd.

2. Scully,C.,2010. Medical Problems in Dentistry, Available at: http://discovery.ucl.ac.uk/ 166609/.

3. Samaranayake, L., 2012. Essential Microbiology for Dentistry 4th Ed. Alison Taylor, ed., Edinburg: Churchill Livingstone Elseiver Ltd

4. Glick M. Burket's Oral Medicine. 12th ed. Connecticut (USA): People's Medical Publishing House; 2015; p104-110

5. Flint, S.R., 2013. Herpes Simplex Virus infection., 1(october), pp.1-7.

6. WHO Update. Herpes Simplex 2017. Available at http://www.who.int/mediacentre /factsheets/fs400/en/

7. DeLong, L. \& Burkhart, N.W., 2013. General and Oral Pathology for the Dental Hygienist 2nd Editio., Philadelphia: Lippincott Williams \& Wilkins.

8. Khan, D., Ahmed, A. The Immune System Is a Natural Target for Estrogen Action: Opposing Effects of Estrogen in Two Prototypical Autoimmune Diseases. 2015. Front Immunol. 6: 635.

9. Guilliams, Thomas G, Edward, Lena. Chronic Stress and the HPA axix: Clinical Assesment and Therapeutic Considerations. 2010. A review of Natural\& nutraceutical therapies for clinical practice.vol.9, No.2.p.1-11.

10. Noisakran, Sansanee, Hallford, Williams, Veress, Livia. Role of the Hypothalamic Pituitary Adrenal Axis and IL-6 in Stress-Induced Reactivation of Latent Herpes simplex Virus Type-1.The American Journal of Immunologists.1998. p.54415447

11. Salvaggio MR, Lutwick LI, Seenivasan M, Kumar S. Herpes simplex. Medscape. available at http://www.emedicine.medscape.com/article/2185 80-overview

12. Chamlin SL, Lawley LP. Perioral dermatitis. In: Wolff K, Goldsmith LA, Katz SI, Gilchrest BA, Paller AS, Leffell DJ. 2008. Fitzpatrick's Dermatology in General Medicine. $7^{\text {th }}$ ed. New York: McGraw Hill Medical, p.709-712 
13. Alpsoy E. Behçet's disease: Treatment of mucocutaneus lesions. Clin Exp Rheumatol. 2005; 23:532-9.

14. Mehta S, Zutshi V, Batra S, Tanwar R. A case of Behçet's disease in pregnancy. JIACM. 2006; Vol. 7, No 3: p:236-8

15. Singh N, dan Colon Y. Patient education and selfadvocacy: Questions and responses on pain management Behçet's disease. J. Pain and Palliative Care Parmacotherapy. 2011; Vol.25 no 3. p.283-5.

16. Singal A, Chhabra N, Pandhi D, Rohatgi J. Behçet's disease in India: A dermatological perspective. Indian Journal of Dermatology, Venereology, and Leprology. 2013;79(2): 199 204.

17. Kaneko F, Togashi A, Saito S, Sakuma H, Oyama N, Nakamura K,. Review article: Behcet disease (Adamantiades-Behcet's Disease). Clinical and Developmental Immunology. 2011; 2011: 1-7.

18. Shwetha BA, Vittal NI, Tasneem AF, Tushar P, Lari AAJ. Case report: Behçet's disease. International Journal of Recent Trends in Science and Technology. 2014; 10(2):33-4.
19. Keogan MT. Clinical immunology review series: An approach to the patient with recurrent orogenital ulceration, including Behçet's syndrome. Clin Exp Immunol.2009; 156(1): 1-11.

20. Sakane T, Takeno M, Suzuki N, Inaba G. Current concept Behçet's disease. The New England Journal of Medicine. 1999; 341(17): 1284-91.

21. Arduino PG, Porter SR. Oral and perioral herpes simplex virus type I (HSV-I) infection : review of its management. Oral Dis. 2006; 12:254-70.

22. Regezi, J., Sciubba, J. \& Jordan, R., 2015. Oral Pathology Clinical Pathologic Correlations, elsevier, p.1-6.

23. Lokanata MD. Pemakaian Glukokortikoid pada Pengobatan. 2006. Jakarta: EGC. p.8-13,15-40

24. Dewoto HR. 2012. Farmakologi dan Terapi. Ed 5. Jakarta: FKUI.p 283,505

25. Sitompul R. Kortikosteroid dalam Tata Laksana Uveitis: Mekanisme Kerja, Aplikasi Klinis, dan Efek Samping. 2011. J Indon Med Assoc. Vol 61. No 6. p 265-9

26. Almatsier, Sunita. 2004. Penuntun Diet edisi baru. Jakarta: PT Gramedia Pustaka Utama.

27. Wiryana, M. Nutrisi Pada Penderita Sakit Kritis. J Peny Dalam 2007.Vol. 8 No 2. p.176-186 